\title{
Metode Waterfall pada Sistem Informasi Pengolahan Data Penjualan dan Pembelian Barang
}

\author{
Rohmat Rifai $^{1}$, Mely Mailasari ${ }^{2}$ \\ ${ }^{1,2}$ Sistem Informasi, Universitas Bina Sarana Informatika \\ Jl. Kramat Raya No. 98, Senen Jakarta Pusat 10450, Telp. (021) 23231170 \\ e-mail: 1rohmatrifai92@gmail.com, ${ }^{2}$ mely.myl@bsi.ac.id
}

Submitted Date: September 03 ${ }^{\text {rd }}, 2020$

Revised Date: September 22nd, 2020
Reviewed Date: September $22^{\text {nd }}, 2020$
Accepted Date: September $30^{\text {th }}, 2020$

\begin{abstract}
Fang Fifi Cell store is one of the shops selling cellphones and accessories in Bekasi. The system used at the Fang Fifi Cell Store is still very manual, starting from data collection, transactions, and reporting. Data collection of goods and transactions still uses handwriting so that recording errors often occur and it is difficult to find data due to accumulation of files. Therefore a problem solving is needed to make it easier for staff to work, namely by making a transaction program and stock goods using the waterfall method, the process is structured and then tested with blackbox testing so thatproduce quality programs that are effective and efficient.This program is expected to support all sales activities and data collection of goods at the Fang Fifi Cell Store as a whole so that it can improve transaction services and inventory data collection as well as making reports.
\end{abstract}

Keywords: Programs; Transactions and Stock of Goods; Waterfall

\section{Abstrak}

Toko Fang Fifi Cell adalah salah satu toko penjualan handphone dan aksesorisnya yang berada di Kota Bekasi. Sistem yang digunakan pada Toko Fang Fifi Cell ini masih sangat manual, mulai dari pendataan barang, transaksi, hingga pembuatan laporan. Pendataan barang dan transaksi masih menggunakan tulis tangan sehingga sering terjadi kesalahan pencatatan dan pencarian data yang sulit karena adanya penumpukan berkas. Oleh karena itu dibutuhkan pemecahan masalah untuk memberikan kemudahan kepada karyawan toko dalam bekerja yaitu dengan dibuatnya sebuah program transaksi dan stock barang menggunakan metode air terjun (waterfall) yang prosesnya terstruktur kemudian di uji dengan blackbox testing sehingga menghasilkan kualitas program yang efektif dan efisien. Program ini diharapkan dapat mendukung seluruh kegiatan penjualan dan pendataan barang pada Toko Fang Fifi Cell secara keseluruhan sehingga dapat meningkatkan pelayanan transaksi dan pendataan stok barang serta pembuatan laporan.

Kata Kunci: Program; Transaksi dan Stok Barang; Waterfall

\section{Pendahuluan}

Menurut Rangkuti dalam (Imaniawan \& Nur, 2019), penjualan adalah memindah ha katas barang dan jasa yang dilakukan penjual dan pembeli dengan harga yang sudah disepakati dengan jumlah yang ditetapkan kepada pembeli pada satu periode akuntansi. Sebelum teknologi berkembang pesat seperti sekarang setiap toko menggunakan kwitansi atau nota sebagai bukti transaksi penjualan kepada pembeli dengan tulis tangan yang membuat transaksi berjalan tidak efektif dan efisien karena untuk pembuatan laporannya harus mencatat lagi ke dalam buku besar melihat dari kumpulan nota atau kwitansi yang ada.

Seperti pada Toko Fang Fifi Cell yang bergerak dalam bidang penjualan handphone dan aksesoris ini pendataan masih sangat manual, mulai dari pendataan barang, transaksi, hingga pembuatan laporan. Pendataan barang dan transaksi masih menggunakan tulis tangan sehingga sering terjadi kesalahan pencatatan dan 
pencarian data yang sulit karena adanya penumpukan berkas.

Karena meningkatnya minat pembelian handphone saat ini, diperlukan sebuah sistem yang sudah terkomputerisasi untuk memudahkan serta mempercepat proses transaksi pada toko handphone. Sistem yang dibuat bukan hanya memindahkan data ke dalam komputer seperti menggunakan Microsoft Excell tetapi sebuah sistem yang dibuat menggunakan program komputer berbasis web dengan data yang sudah tersimpan dalam database. Website adalah sekumpulan halaman yang berisi informasi dalam bentuk data digital baik berupa teks, gambar, video, audio dan lainnya yang tersedia melalui koneksi internet (Abdulloh, 2016). Sedangkan database sendiri memiliki arti kumpulan data yang menggambarkan aktifitas dan penggunanya dalam organisasi (Hendini, 2016).

Dengan perkembangan teknologi sekarang, sebuah website tidak hanya difungsikan untuk menampilkan informasi saja tetapi website kini dijadikan salah satu wadah untuk kegiatan berjualan secara online. Dengan website tersebut penjual dapat dengan mudah mempromosikan produk yang akan dijual dan mempermudah masyarakat untuk mengetahui informasi produk yang akan dibeli (Mulyana \& Agustina, 2016).

Penelitian (Abdurahman, 2017) pada Toko Koloncucu Kota Ternate membuat sebuah sistem yang diharapkan dapat menunjang pelayanan dan kinerjanya dalam mengelola data pembelian dan penjualan berbasis web menggunakan database karena data pembelian dan penjualan masih dicatat dalam buku dan kesulitan dalam pengontrolan stok.

Penelitian (Siregar, 2017), pengolahan data pembelian dan penjualan pakaian pada Galoenk Distro Pematang Siantar masih dicatat ke dalam faktur dan buku kas sehingga perlu dirancang sebuah sistem informasi untuk mengolah transaksi penjualan dan pembelian menggunakan Microsoft Visual Studio 2012 agar menghasilkan laporan yang tepat dan akurat.

Pada penelitian (Sari, Kurniawan, Arianto, \& Adrianto, 2017) dijelaskan untuk pengolahan data produksi dan transaksi penjualan es balok menggunakan Microsoft Excell dirasa kurang efisien karena pada pembuatan laporan membutuhkan waktu yang lama dalam melakukan perhitungannya sehingga diperlukan sistem untu mengelola data produksi dan transaksi penjualan es balok menggunakan bahasa pemrograman PHP untuk meminimalisir terjadinya redudan data dan penghematan waktu dalam pencarian data sehingga menjadi efisien.

Berdasarkan beberapa penelitian terdahulu yang sudah dijabarkan tersebut, maka peneliti membuat sebuah sistem informasi pengolahan data penjualan dan pembelian barang pada Fang Fifi Cell dengan menggunakan metode waterfall berbasis website melalui pengujian blackbox testing.

\section{Metodologi Penelitian}

Gambaran langkah-langkah yang akan digunakan dalam merumuskan masalah dalam suatu kegiatan penelitian:

A. Metode Pengembangan Perangkat Lunak

Waterfall adalam metode pengembangan perangkat lunak yang akan digunakan dalam penelitian ini. (Tristianto, 2018) menyimpulkan waterfall merupakan proses mengembangkan perangkat lunak yang langkahnya dilakukan secara berurut dan bertahap meliputi tahapan perencanaan, pemodelan, implementasi dan pengujian.

Berikut adalah langkah-langkah yang ada pada metode waterfall:

1. Analisa Kebutuhan

Menganalisa kebutuhan yang diperlukan untuk membuat aplikasi pengolahan data penjualan dan pembelian barang pada toko Fang Fifi Cell.

2. Perancangan Sistem Dan Perangkat Lunak

Merancang desain input dan output menggunakan Entity Relationship Diagram (ERD) dan Logical Record Structure (LRS) sebagai gambarannya. Menurut Simarmata dan Paryudi dalam (Oktaviani, Sarkawi, \& Priadi, 2018), ERD adalah suatu model yang membantu mengorganisasi data ke suatu proyek dalam bentuk entitas-entitas dengan menentukan relasi antar entitasnya. Setelah itu kumpulan dari record yang ada di ERD ditransformasikan dalam bentuk kotak persegi panjang dengan nama yang unik, inilah yang dinamakan dengan LRS. Rancangan program dibuat dengan bahasa pemrograman PHP sedangkan databasenya menggunakan MySQL.

3. Implementasi dan Pengujian Unit

Tahapan ini adalah tahapan terakhir. Setelah melalui tahapan diatas dan program sudah dibuat dilakukan pengujian unit menggunakan blackbox testing. Menurut (Cholifah, Yulianingsih, \& Sagita, 2018), metode blackbox memperkirakan banyaknya data yang diuji dapat diolah melalui banyaknya field data 
entri yang akan diuji sehingga dapat diketahui jika data yang diinput tidak sesuai yang diharapkan akan menyebabkan data yang disimpan kurang valid.

\section{B. Teknik Pengumpulan Data}

Berikut beberapa teknik yang digunakan dalam pengumpulan data:

1. Observasi

Penulis melihat serta mengamati prosesproses yang terjadi pada sistem transaksi dan penyimpanan data-data di toko Fang Fifi Cell.

2. Wawancara

Wawancara dilakukan dengan pemilik toko yaitu Ibu Fifi. Beberapa pertanyaan di ajukan kepada pemilik toko, seperti proses transaksi dan penyimpanan data.

3. Studi Pustaka

Studi pustaka dilakukan untuk mencari referensi-referensi dari berbagai sumber untuk membangun program yang akan dibuat.

\section{Pembahasan}

Tahapan awal untuk membuat sebuah sistem baru yang terkomputerisasi setelah adanya proses identifikasi terhadap masalah yang dihadapi oleh pengguna sistem disebut dengan analisa kebutuhan. Pada penelitian ini dibuat dua analisa kebutuhan yaitu pengguna dan sistem. Pada analisa kebutuhan pengguna terdapat dua pengguna yaitu admin dan kasir. Admin diharuskan login dengan memasukan username dan password yang akan divalidasi oleh sistem, admin dapat mengakses dan mengelola keseluruhan sistem yang ada mulai dari pembelian barang, pendataan barang hingga pencetakan laporan penjualan. Sedangkan kasir juga diharuskan login untuk hak akses miliknya dengan menginput username dan password, lalu kasir dapat menginput transaksi penjualan kemudian mencetak struk untuk diberikan kepada pembeli.

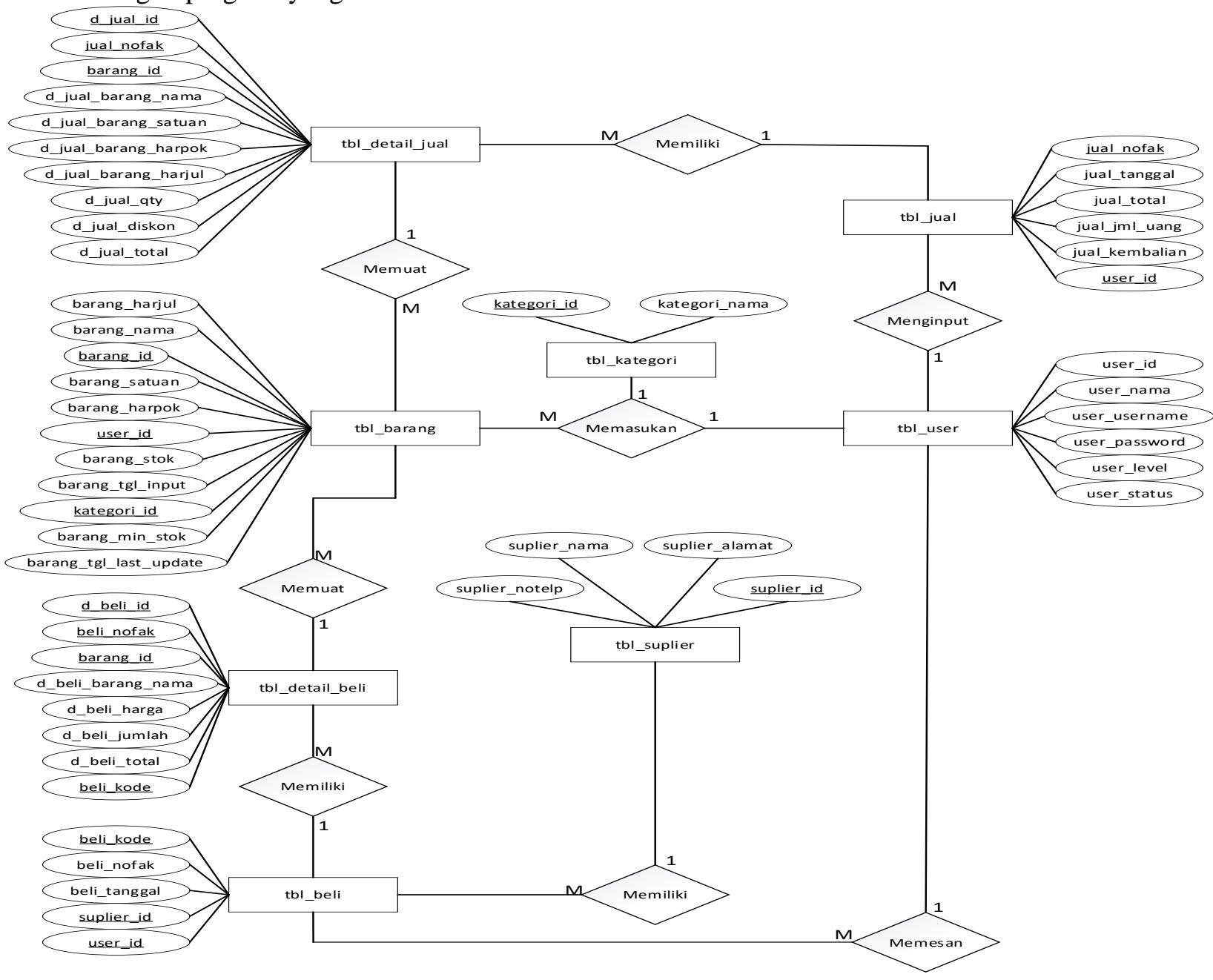

Gambar 1. Entity Relationship Diagram 
Sistem menyediakan dua form login dengan hak aksesnya masing-masing. Hak akses tersebut digunakan oleh admin dan kasir untuk menjalankan sistem sesuai dengan kewenangannya. Admin dapat mengelola keseluruhan manajemen yang ada pada sistem sedangkan kasir hanya diberi akses untuk mengelola transaksi penjualan dan mencetak struk atau faktur.
Tahapan kedua yaitu mendesain rancangan dokumen menggunakan Entity Relationship Diagram yang digambarkan pada Gambar 1 .

Dengan Logical Record Structure yang merupakan transformasi dari gambaran ERD diatas digambarkan seperti Gambar 2 di bawah ini:

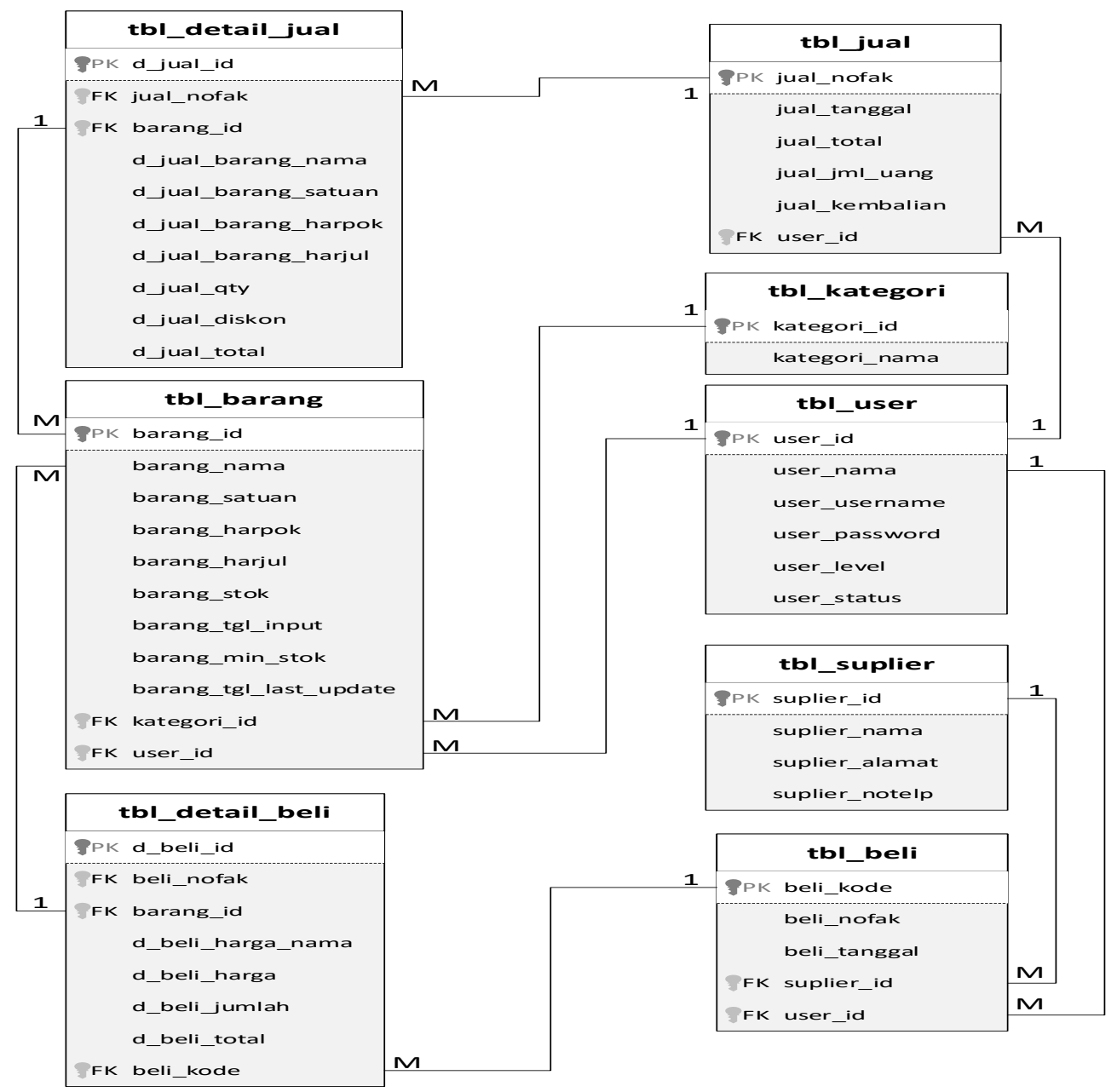

Gambar 2. Logical Record Structure

Rancangan struktur navigasi dibuat menjadi dua karena terdapat dua pengguna yaitu admin dan kasir. Dapat dilihat pada gambar 3. ditampilkan semua menu yang dapat diakses oleh admin. Sedangkan pada Gambar 4. Struktur navigasi kasir hanya menampilkan menu transaksi yang dapat diakses. 


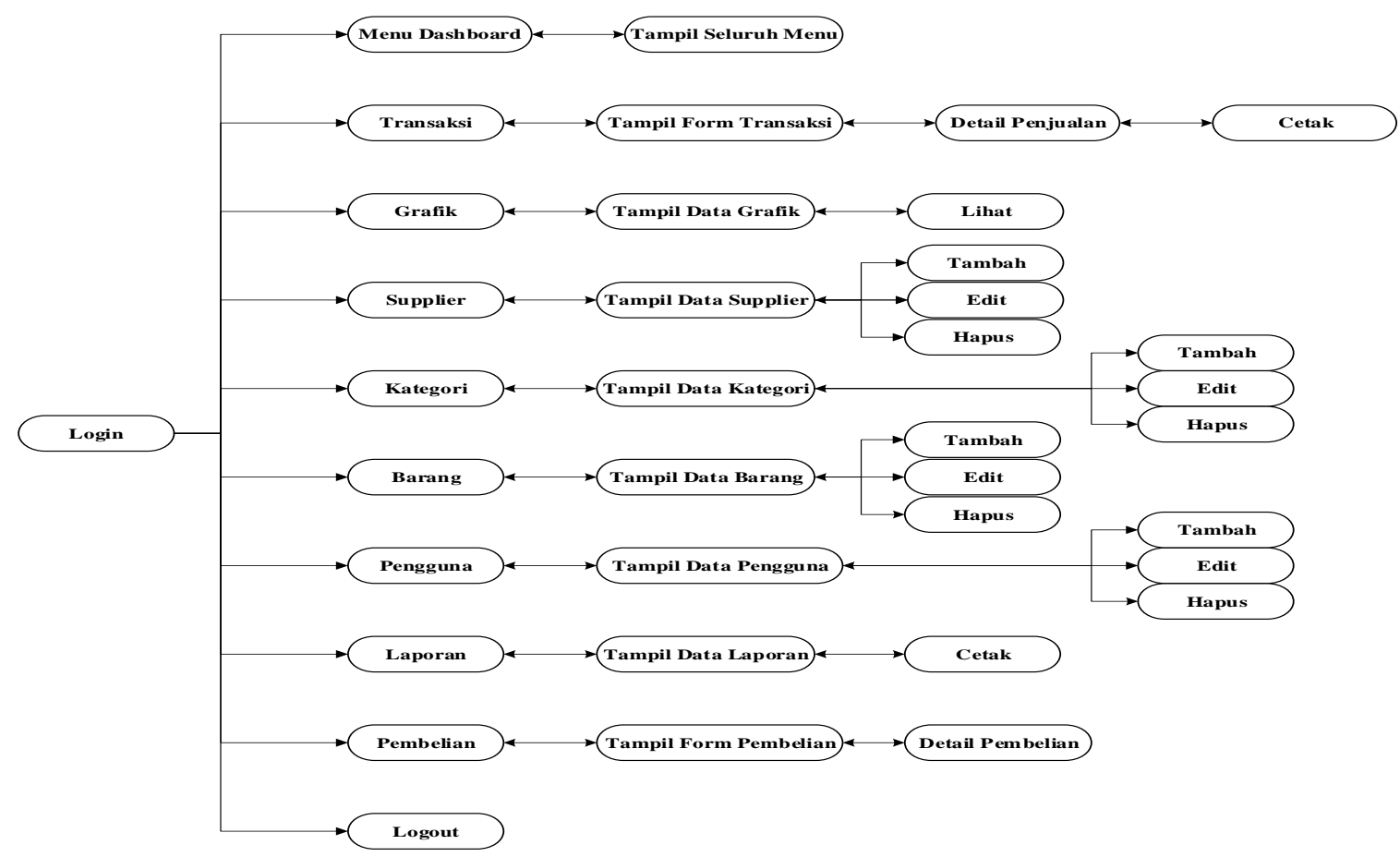

Gambar 3. Struktur Navigasi Admin

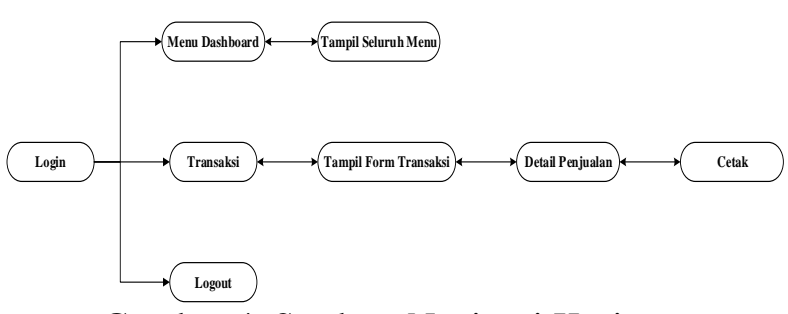

Gambar 4. Struktur Navigasi Kasir

Dalam merancang sistem informasi penjualan dan pembelian ini, diperlukan pengkodean dengan tujuan untuk mengidentifikasi data, pemanggilan program tertentu, pengisian data atau kolom agar memudahkan pengelolaan data. Suatu kode berguna untuk memanggil seluruh field yang terhubung dengan kode tersebut secara otomatis sesuai dengan perintah yang diberikan.

1. Kode Barang

Masing-masing barang wajib memiliki kode sehingga dapat dibedakan dengan barang lainnya.

\begin{tabular}{|c|c|c|c|c|c|}
\hline $\mathbf{B}$ & $\mathbf{R}$ & - & $\mathbf{0}$ & $\mathbf{0}$ & $\mathbf{1}$ \\
\multicolumn{2}{|c|}{$\underbrace{}_{\text {Nomor Urut }}$}
\end{tabular}

Keterangan :

$\mathrm{BR}=$ Untuk Identitas Barang

$001=$ Untuk Nomor Urut Barang
2. Kode Pembelian Barang

Kode pembelian di buat agar tidak terjadi pemalsuan data.

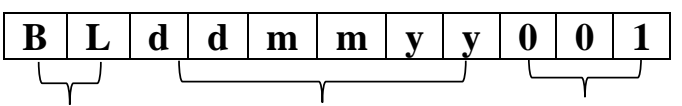

Identitas Beli Tanggal Nomor Urut

Keterangan:

BL =Untuk Identitas Pembelian

ddmmyy $=$ Untuk Tanggal Transaksi

$001=$ Untuk Nomor Urut pembelian

3. Kode Faktur Penjualan

Setiap melakukan penjualan suatu barang harus ada kode khusus untuk mencegah adanya pemalsuan data.

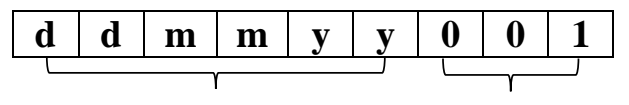

Tanggal Transaksi Nomor Urut

Keterangan :

ddmmyy $=$ Tanggal Penjualan

$001=$ Nomor Urut Penjualan

4. Kode Supplier

Satu supplier harus memiliki kode yang berbeda dengan supplier lainnya agar tidak terjadi kesamaan data. 


\begin{tabular}{|l|l|l|l|l|l|l|}
\hline $\mathbf{S}$ & $\mathbf{P}$ & $\mathbf{L}$ & - & $\mathbf{0}$ & $\mathbf{0}$ & $\mathbf{1}$ \\
\hline
\end{tabular}

Identitas Supplier Nomor Urut

Keterangan:

SPL = Untuk Identitas Supplier.

$001=$ Untuk Nomor Urut

5. Kode Kategori

Untuk membedakan kategori satu dengan yang lainnya maka harus diberikan kode.

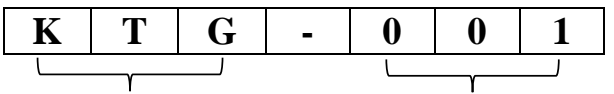

Identitas Kategori Nomor Urut

Keterangan :

KTG = Untuk Identitas Kategori

$001=$ Untuk Nomor Urut

Tahapan ketiga adalah implementasi dimana pada tahapan ini sistem mulai terbangun seperti berikut:

1. Halaman Login Admin dan Kasir

Pengguna harus login lebih dahulu agar dapat mengelola data-data di halaman menu utama.

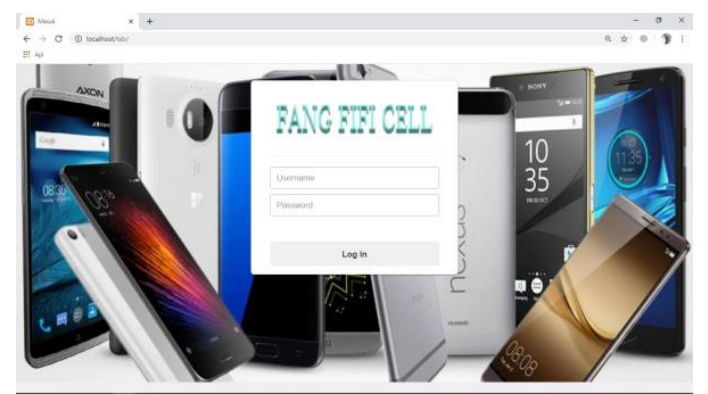

Gambar 5. Halaman Login

2. Halaman Menu Utama

Setelah login dan data tervalidasi dengan benar, maka sistem akan menampilkan menu utamanya.

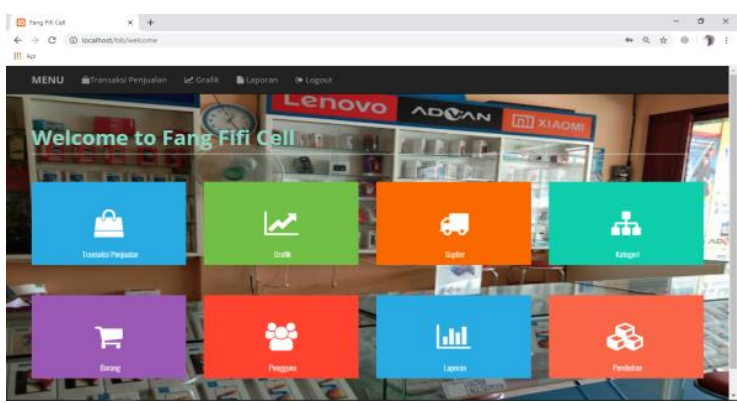

Gambar 6. Halaman Menu Utama
3. Halaman Transaksi Penjualan

Di halaman ini admin dan kasir dapat melakukan proses transaksi dan mencetak faktur penjualan.
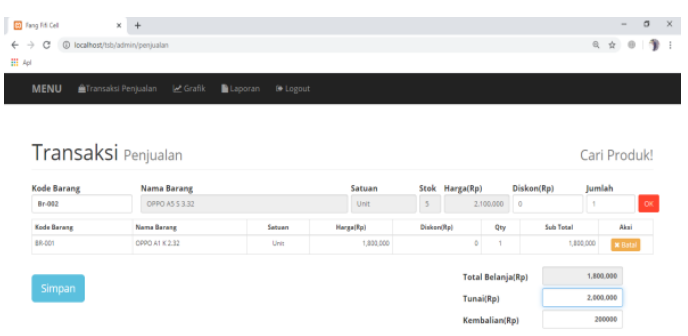

Gambar 7. Halaman Transaksi Penjualan

4. Halaman Supplier

Halaman ini berguna untuk menginput data supplier.
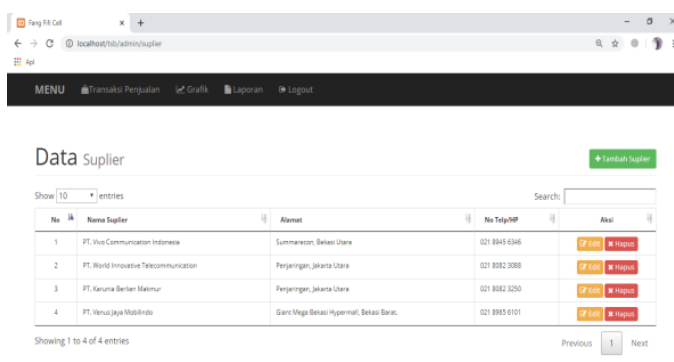

Gambar 8. Halaman Supplier

5. Halaman Kategori

Halaman ini berguna untuk menginput data kategori.
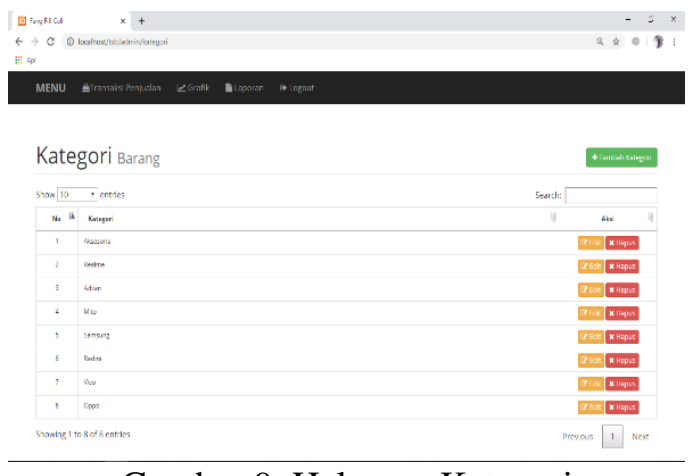

Gambar 9. Halaman Kategori

6. Halaman Barang

Halaman ini berguna untuk menginput data barang. 


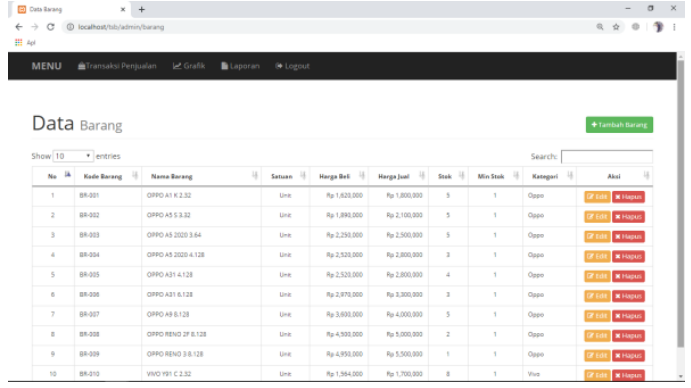

Gambar 10. Halaman Barang

7. Halaman Laporan

Halaman ini berguna untuk melihat dan mencetak laporan.

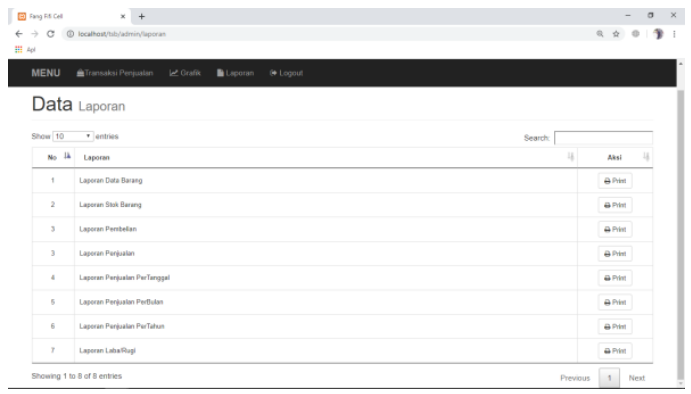

Gambar 11. Halaman Laporan

8. Halaman Pembelian

Halaman ini berguna untuk menginput data pembelian dari supplier.
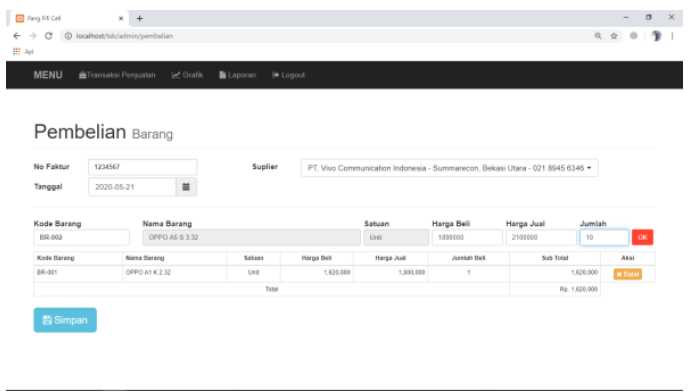

Gambar 12. Halaman Pembelian

9. Faktur Penjualan

Faktur penjualan ini berguna sebagai bukti tanda terima ke customer bahwa telah terjadi proses transaksi.

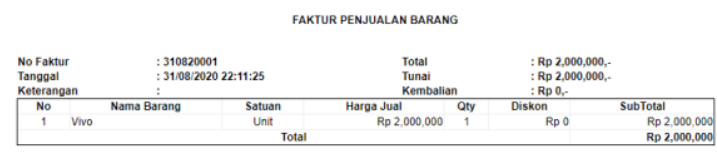

Gambar 13.Faktur Penjualan

\section{Kesimpulan}

Kesimpulan dalam pembuatan penelitian ini sebagai berikut:

a. Dapat mempermudah pekerjaan dalam pengelolaan data.

b. Dapat mengurangi kesalahan-kesalahan pada sistem yang masih menggunakan cara konvensional.

c. Dapat disimpan dengan jumlah yang banyak dan aman karena telah menggunakan password.

d. Dapat mengurangi terjadinya duplikasi data.

\section{Saran}

Saran pada penelitian ini guna perbaikan sistem yang lebih baik lagi diantaranya:

a. Perlu adanya pelatihan bagi user baru untuk menjalankan program yang penulis buat.

b. Perlu dilakukan pengecekan berkala serta pembaruan sistem untuk menjaga dan meningkatkan kualitas sistem tersebut.

c. Perlu adanya keamanan data agar terhindar dari pengguna yang tidak berkepentingan.

\section{Referensi}

Abdulloh, R. (2016). Easy \& Simple Web Programming. Jakarta: PT. Elex Media Komputindo.

Abdurahman, M. (2017). Sistem Informasi Pengolahan Datta Pembelian Dan Penjualan Pada Toko Koloncucu Ternate IJIS. IJIS - Indonesian Journal On Information System, 2(1), 18-26. Retrieved from http://ijiswiratama.org/index.php/home/article/vie $\mathrm{w} / 22 / 19$

Cholifah, W. N., Yulianingsih, Y., \& Sagita, S. M. (2018). Pengujian Black Box Testing pada Aplikasi Action \& Strategy Berbasis Android dengan Teknologi Phonegap. STRING (Satuan Tulisan Riset Dan Inovasi Teknologi), 3(2), 206. https://doi.org/10.30998/string.v3i2.3048

Hendini, A. (2016). Pemodelan Uml Sistem Informasi Monitoring Penjualan Dan Stok Barang (Studi Kasus: Distro Zhezha Pontianak). Jurnal Khatulistiwa Informatika, IV(2), 107-116. https://doi.org/https://doi.org/10.31294/jki.v4i2.1 262.g1027

Imaniawan, F. F. D., \& Nur, H. M. (2019). Perancangan Dan Pembuatan Website Penjualan Biji Kopi Pada Society Coffee House Purwokerto. EVOLUSI - Jurnal Sains Dan Manajemen, $\quad 7(1), \quad 61-67$. https://doi.org/10.31294/evolusi.v7i1.5030

Mulyana, U., \& Agustina, D. (2016). Perancangan Sistem Informasi Penjualan Handphone Berbasis Web Pada Toko Ilham Cellular Jakarta. Ilmiah 
Fifo, $\operatorname{VIII}(2), 161-172$.

Oktaviani, A., Sarkawi, D., \& Priadi, A. (2018). Perancangan Aplikasi Penjualan Dengan Metode Waterfall Pada Koperasi Karyawan Rsud Pasar Rebo. Petir, 11(1), 9-24. https://doi.org/10.33322/petir.v11i1.3

Sari, U. Y., Kurniawan, R., Arianto, A., \& Adrianto, S. (2017). Sistem Pengolahan Data Produksi Dan Penjualan Es Balok Pada Upt Ppi Kota Dumai. Jurnal Informatika, Manajemen Dan Komputer, 9(2), 51-59. https://doi.org/http://dx.doi.org/10.36723/juri.v9i 2.104

Siregar, V. M. M. (2017). Sistem Informasi Pembelian dan Penjualan Pakaian pada Galoenk Distro Pematangsiantar. Jurnal Teknologi Informasi, 1(2), 219-227. https://doi.org/https://doi.org/10.36294/jurti.v1i2. 299

Tristianto, C. (2018). Penggunaan Metode Waterfall Untuk Pengembangan Sistem Monitoring Dan Evaluasi Pembangunan Pedesaan. Jurnal Teknologi Informasi ESIT, XII(01), 8-22. Retrieved from http://jurnaleresha.ac.id/index.php/esit/article/view/51 